\title{
Malonyl-COA and the regulation of fatty acid oxidation in soleus muscle
}

\author{
Nasreen ALAM and E. David SAGGERSON ${ }^{1}$ \\ Department of Biochemistry and Molecular Biology, University College London, Gower Street, London WC1E 6BT, U.K.
}

1. Rat soleus strips were incubated with $5 \mathrm{mM}$ glucose, after which tissue metabolites were measured. Alternatively, muscle strips were incubated with $5 \mathrm{mM}$ glucose and $0.2 \mathrm{mM}$ palmitate, and the formation of ${ }^{14} \mathrm{CO}_{2}$ from exogenous palmitate or from fatty acids released from prelabelled glycerolipids was measured. 2. Etomoxir, which inhibits the mitochondrial overt form of carnitine palmitoyltransferase $\left(\mathrm{CPT}_{1}\right)$, increased the tissue content of long-chain fatty acyl-CoA esters and decreased the ratio of fatty acylcarnitine to fatty acyl-CoA, suggesting that such changes could be a diagnostic for the inhibition of CPT . $_{1}$

3. Over a range of incubation conditions there was a positive correlation between the tissue contents of malonyl-CoA and long-chain fatty acyl-CoA esters. Under conditions in which these two metabolites increased in content (i.e. with insulin or with $3 \mathrm{mM}$ dichloroacetate) there was a corresponding decrease in the ratio of fatty acylcarnitine to fatty acyl-CoA and a decrease in $\beta$-oxidation. Isoprenaline or palmitate $(0.5 \mathrm{mM})$ opposed the effect of insulin, decreasing the contents of malonyl$\mathrm{CoA}$ and long-chain fatty acyl-CoA, increasing the ratio of fatty acylcarnitine to fatty acyl-CoA and increasing $\beta$-oxidation. These findings are consistent with the notion that all of these agents can cause the acute regulation of $\mathrm{CPT}_{1}$ in Type I skeletal muscle. 4. The addition of 5-amino-4-imidazolecarboxamide ribonucleoside (AICAriboside) to cause activation of the AMPactivated protein kinase decreased the tissue content of malonylCoA. AICAriboside also had an antilipolytic effect in the muscle strips.

5. Measurements were made of the activities of ATP-citrate lyase, acetyl-CoA carboxylase, fatty acid synthase and malonylCoA decarboxylase in soleus muscle and in representative Type IIa and Type IIb muscles. A cytosolic activity of malonyl-CoA decarboxylase would seem to offer a feasible route for the disposal of malonyl-CoA in skeletal muscle.

\section{INTRODUCTION}

As recently reviewed [1], the inhibition of the overt form of carnitine palmitoyltransferase $\left(\mathrm{CPT}_{1}\right)$ that is associated with the outer membrane of mitochondria by malonyl-CoA has, in conjunction with acetyl-CoA carboxylase (ACC; EC 6.4.1.2), a pivotal role in tissue fuel homoeostasis. This concept was originally developed in the context of reciprocal regulation of long-chain fatty acid oxidation and synthesis in the liver. More

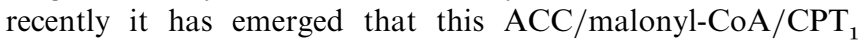
system is also involved in fuel sensing and selection in muscle. Heart and skeletal muscle mitochondria contain a $\mathrm{CPT}_{1}$ isoform distinct from liver $\mathrm{CPT}_{1}$ [1] that is more sensitive to inhibition by malonyl-CoA than the liver enzyme [2-4]. These non-lipogenic tissues also contain appreciable levels of malonyl-CoA, generated by a distinct isoform of ACC [5-8].

The 'glucose fatty acid cycle' concept proposed by Randle et al. [9] explained why the increased provision of fat-derived fuels such as non-esterified fatty acids or ketone bodies led to the inhibition of glycolysis and glucose oxidation in perfused hearts or in incubated diaphragms. As recently revised [10], this ' glucose sparing' effect depends on the oxidation of fat-derived fuels and centres on the regulation of pyruvate dehydrogenase and phosphofructokinase 1. Under appropriate experimental conditions it has been possible to extend the concept of the 'glucose fatty acid cycle' to oxidative types of skeletal muscle [11-16].

Studies with heart showed that there are circumstances in which muscle fuel selection can be driven in the reverse of that envisaged in the 'glucose fatty acid cycle'. An increased supply of lactate decreases fatty acid oxidation by the heart [17-21] or by cardiac myocytes [22,23]. Glucose suppresses fatty acid oxidation in similar experiments $[21,23,24]$ and dichloroacetate (DCA), an inhibitor of pyruvate dehydrogenase kinase, enhances these effects [21]. Involvement of the ACC/malonyl-CoA/CPT system in these 'reverse glucose fatty acid cycle' effects was implied because carbohydrate fuels inhibit the oxidation of oleate but not that of octanoate [21] and decrease the tissue content of long-chain fatty acylcarnitines [20]. Also, the addition of insulin to hearts perfused with glucose results in an increase in the myocardial content of malonyl-CoA [23].

In skeletal muscle the ACC/malonyl-CoA/CPT 1 system seems to be involved both in 'reverse glucose fatty acid cycle' events and in fuel sensing during contraction or exercise. In humans hyperinsulinaemia under euglycaemic conditions causes the suppression of fatty acid oxidation by skeletal muscle [25] and hyperinsulinaemic/hyperglycaemic clamp conditions lead to the decreased oxidation of oleate and a decreased muscle content of long-chain fatty acylcarnitine [26]. The content of malonyl-CoA is increased by glucose and insulin in an interdependent fashion in rat soleus muscle [27,28] and is decreased by fasting in rat quadriceps muscle [29]. Neither of these changes in malonyl-CoA is accompanied by any alteration in the kinetic properties of ACC $[28,29]$. The effects of glucose/insulin on soleus muscle malonyl-CoA content seem to reflect the increased provision of

Abbreviations used: ACC, acetyl-CoA carboxylase (EC 6.4.1.2); AlCAriboside, 5-amino-4-imidazolecarboxamide ribonucleoside; AMPK, AMPactivated protein kinase; $\mathrm{CPT}_{1}$, the overt form of mitochochondrial carnitine palmitoyltransferase (EC 2.3.1.22); CS, citrate synthase (EC 4.1.4.7); DCA, dichloroacetate; EDL, extensor digitorum longus; MDC, malonyl-CoA decarboxylase (EC 4.1.1.9); ZMP, 5-amino-4-imidazolecarboxamide ribonucleoside monophosphate.

1 To whom correspondence should be addressed (e-mail saggerson@bsm.biochemistry.ucl.ac.uk). 
acetyl-CoA and citrate, respectively the substrate and the allosteric activator of ACC [28]. In contrast the decrease in malonylCoA content in rat skeletal muscle during exercise [30,31] or during contraction $[32,33]$ seems to result from the inactivation of ACC through protein phosphorylation by the AMP-activated protein kinase (AMPK) [30,32,33] (reviewed in [34]). Although inferences about the allosteric activation or inhibition of $\mathrm{CPT}_{1}$ within muscle can be drawn from changes in malonyl-CoA, the above studies did not provide any other measurements that might reinforce these inferences. Here we have adopted the approach of combining measurements of malonyl-CoA and of the fatty acyl-CoA substrate and fatty acylcarnitine product of $\mathrm{CPT}_{1}$ with measurements of $\beta$-oxidation metabolic flux. These measurements have been made with isolated rat soleus muscle (89\% slow-twitch red fibres and $11 \%$ fast-twitch red fibres [27]), which can be conveniently incubated. We find evidence to support the notion that muscle $\mathrm{CPT}_{1}$ is inhibited by insulin or DCA and is activated in response to isoprenaline, increased fatty acid supply and 5-amino-4-imidazolecarboxamide ribonucleoside (AICAriboside) (which can lead to the activation of AMPK). We have also studied the effects of some of these agents on muscle lipolysis and assessed the potential for cytosolic synthesis and disposal of malonyl-CoA in skeletal muscles.

\section{MATERIALS AND METHODS}

\section{Chemicals}

Routinely used chemicals were from British Drug Houses (Poole, Dorset, U.K.), Sigma Chemical Co. (Poole, Dorset, U.K.) or Boehringer Mannheim (Lewes, East Sussex, U.K.). Radiochemicals were from Amersham International (Little Chalfont, Bucks., U.K.). Fatty acid synthase (EC 2.3.1.85) was purified from rat liver [23] with a specific activity of at least $100 \mathrm{nmol} / \mathrm{min}$ per $\mathrm{mg}$ of protein at $25^{\circ} \mathrm{C}(100 \mathrm{~m}$-units $/ \mathrm{mg})$. Sodium palmitate was bound to fatty acid-poor bovine albumin [35] and the concentration of bound palmitate determined with a Wako NEFA C test kit (Alpha Laboratories, Eastleigh, Hants., U.K.).

\section{Animals}

Male Sprague-Dawley rats (180-200 g) were maintained at 20-22 ${ }^{\circ} \mathrm{C}$ on a $13 \mathrm{~h}$ light $/ 11 \mathrm{~h}$ dark cycle with light from $06: 00 \mathrm{~h}$ to $19: 00 \mathrm{~h}$ with constant access to drinking water and Rat \& Mouse Breeding Diet (Special Diet Services, Witham, Essex, U.K.). The diet contained (by wt.) $21 \%$ protein, $4 \%$ fat and $39 \%$ starches and sugars.

\section{Incubation of soleus muscle strips for measurement of metabolite contents}

Soleus muscle strips (approx. $35 \mathrm{mg}$ ) were obtained by longitudinal dissection, tied via the tendons under light tension to stainless steel clips [36] (Spring \& Wire Form, Reading, Berks., U.K.) and preincubated for $30 \mathrm{~min}$ at $37^{\circ} \mathrm{C}$ under $\mathrm{O}_{2} / \mathrm{CO}_{2}$ (19:1) in $4 \mathrm{ml}$ of Krebs Henseleit Bicarbonate medium with fatty acid-poor albumin $(20 \mathrm{mg} / \mathrm{ml})$ and $5 \mathrm{mM}$ glucose. The muscle strips were then transferred to $4 \mathrm{ml}$ of the same medium with additions as indicated in Tables 1 and 2. After incubation for a further $1 \mathrm{~h}$ the strips were plunged into liquid nitrogen. Two frozen strips, each originating from a separate rat, were pooled and ground to a powder followed by the addition of $6 \%(\mathrm{w} / \mathrm{v})$ $\mathrm{HClO}_{4}(10 \mu \mathrm{l} / \mathrm{mg}$ of muscle). The frozen material was homogenized with an Ultra-Turrax tissue disintegrator followed by centrifugation at $2000 \boldsymbol{g}_{\text {av }}$ for $10 \mathrm{~min}$. The resulting supernatant was adjusted to $\mathrm{pH} 6.0$ by the adddition of $5 \mathrm{M}$ potassium bicarbonate. The extract was centrifuged as before and the

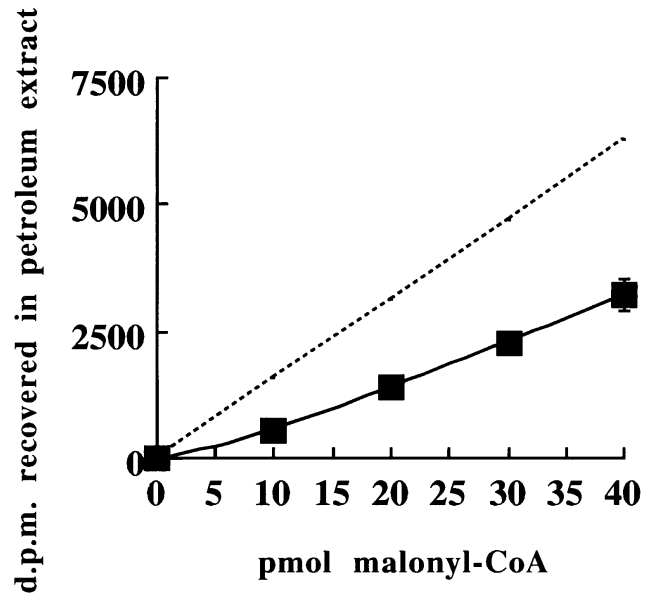

Figure 1 Standard curve for assay of small amounts of malonyl-CoA

The values $(\square)$ are means \pm S.E.M. for 25 different experiments. The dotted line shows the theoretical result if all malonyl-CoA were converted into $\left[{ }^{3} \mathrm{H}\right]$ palmitate. With 100-200 pmol of malonyl-CoA this theoretical result was obtained (results not shown).

supernatant was used for measurements of malonyl-CoA and 5amino-4-imidazolecarboxamide ribonucleoside monophosphate (ZMP). The $\mathrm{HClO}_{4}$-insoluble pellet was homogenized in $1.5 \mathrm{ml}$ of $0.2 \mathrm{M} \mathrm{KOH}$ containing $10 \mathrm{mM}$ dithiothreitol and then incubated at $55^{\circ} \mathrm{C}$ for $2 \mathrm{~h}$, after which it was cooled in ice and $75 \mu \mathrm{l}$ of $60 \%$ (w/v) $\mathrm{HClO}_{4}$ was added. After centrifugation $\left(2000 \boldsymbol{g}_{\text {av }}\right.$ for $10 \mathrm{~min}$ ) the resulting supernatant was buffered by the addition of $25 \mu \mathrm{l}$ of near-saturated $\mathrm{KH}_{2} \mathrm{PO}_{4}$ and the $\mathrm{pH}$ was raised to 7.0 with $\mathrm{KOH}(10 \mathrm{M}$ and then $1 \mathrm{M})$. After centrifugation as before, the supernatant was used for measurements of CoA and carnitine liberated by the hydrolysis of long-chain fatty acyl-CoAs and acylcarnitines respectively.

Malonyl-CoA was measured radiochemically as described [37], with some modifications. Assays were in $1 \mathrm{ml}$ of $0.2 \mathrm{M}$ potassium phosphate buffer ( $\mathrm{pH} 7.2) / 0.2 \mathrm{mM}$ EDTA $/ 2.5 \mathrm{mM}$ dithiothreitol $/ 1 \mathrm{mg} / \mathrm{ml}$ fatty acid-poor albumin $/ 0.25 \mathrm{mM} \mathrm{NADPH} /$ $0.68 \mu \mathrm{M}\left[{ }^{3} \mathrm{H}\right]$ acetyl-CoA $(0.5 \mu \mathrm{Ci} / \mathrm{nmol})$ containing either $150 \mu \mathrm{l}$ of $\mathrm{HClO}_{4}$-soluble muscle extract or $0,10,20,30$ or $40 \mathrm{pmol}$ of malonyl-CoA standard. The reaction was initiated by $1 \mathrm{~m}$-unit of fatty acid synthase followed by incubation for $2 \mathrm{~h}$ at $37^{\circ} \mathrm{C}$. The reaction was then stopped and ${ }^{3} \mathrm{H}$-labelled petroleumsoluble product was extracted as described [37]. The assay typically measured 100-200 pmol of malonyl-CoA from rat liver, in which tissue malonyl-CoA contents are relatively high and where quantity of tissue is not a problem. The assays [37] were calibrated by the addition of malonyl-CoA as internal standard to overcome the problem of dilution of $\left[{ }^{3} \mathrm{H}\right]$ acetyl-CoA in the assay by unlabelled acetyl-CoA from the tissue extract. Under the conditions used [37], the assay product was essentially all $\left[{ }^{3} \mathrm{H}\right]$ palmitate and product formation was linear with malonylCoA concentration. However, to measure malonyl-CoA reliably in small muscle strips (10-30 pmol in a typical assay) we had to modify the assay as described in [37]. This was because, as noted by Singh et al. [38], we found that the assay was non-linear at low malonyl-CoA concentrations (Figure 1). This could be due to the binding of some malonyl-CoA by the fatty acid synthase or, as the ratio of acetyl-CoA to malonyl-CoA in the assay is relatively high, owing to the premature release from the fatty acid synthase complex of short-chain or medium-chain reaction products [39] that are incompletely extracted into petroleum or are lost during 
drying down of the petroleum fraction. To minimize the problem of binding of malonyl-CoA we decreased the concentration of fatty acid synthase to $1 \mathrm{~m}$-unit per assay (and accordingly lengthened the incubation time to $2 \mathrm{~h}$ ) but still observed a sufficient lack of linearity to preclude the use of internal standards. However, we concluded that these were unnecessary in view of the small amounts of tissue used. On the assumption that $1 \mathrm{~g}$ of skeletal muscle contains $0.65 \mathrm{~g}$ of intracellular water, rat soleus muscle contains $2.7-5.2 \mathrm{nmol}$ of acetyl-CoA per $\mathrm{g}$ wet wt. [40,41]. Under our conditions this would cause no more than a 5-9\% dilution of the $\left[{ }^{3} \mathrm{H}\right]$ acetyl-CoA in the assay. Accordingly, assays of malonyl-CoA in muscle extracts were calibrated by reference to external standards that were always assayed in parallel on the same day. The recovery of added malonyl-CoA taken through the tissue extraction procedure was $85-90 \%$, and the contents of malonyl-CoA in soleus muscle were similar to published values $[27,28,42]$.

ZMP was measured by HPLC. Samples were applied to a $15 \mathrm{~cm} \times 4 \mathrm{~mm}$ column of APS-Hypersil-5 equilibrated with $5 \mathrm{mM}$ $\mathrm{KH}_{2} \mathrm{PO}_{4}, \mathrm{pH} 3.0$, at a flow rate of $1 \mathrm{ml} / \mathrm{min}$ followed by a linear gradient up to $500 \mathrm{mM} \mathrm{KH}_{2} \mathrm{PO}_{4}$, $\mathrm{pH} 3.0$, over $20 \mathrm{~min}$. ZMP had a retention time of $10.2 \mathrm{~min}$ and was identified by reference to a ZMP standard. CoA derived from long-chain fatty acyl-CoAs was measured by a sensitive recycling assay [43]. Carnitine derived from long-chain acylcarnitines was measured by the method of Cederblad and Lindstedt [44].

\section{Measurement of fatty acid oxidation by incubated soleus muscle strips}

Muscle strips were preincubated for $30 \mathrm{~min}$ as described above except that incubations additionally contained sodium palmitate $\left(0.2 \mathrm{mM}\right.$ unless otherwise stated) with or without $\left[\mathrm{U}-{ }^{14} \mathrm{C}\right] \mathrm{pal}-$ mitate $(0.1 \mu \mathrm{Ci} / \mu \mathrm{mol})$. Subsequently the strips were washed in Krebs Henseleit Bicarbonate medium and transferred to fresh flasks fitted with centre wells. Strips that had been preincubated with unlabelled palmitate were then used for the measurement of oxidation of exogenous fatty acid by incubation in $4 \mathrm{ml}$ of Krebs Henseleit Bicarbonate medium containing fatty acid-poor albu$\min (20 \mathrm{mg} / \mathrm{ml}), 5 \mathrm{mM}$ glucose, $0.2 \mathrm{mM}\left[\mathrm{U}-{ }^{14} \mathrm{C}\right]$ palmitate and the additions shown in Table 2 . Strips that had been preincubated with ${ }^{14} \mathrm{C}$-labelled palmitate were used for measurement of the oxidation of fatty acids from endogenous sources by incubation in $4 \mathrm{ml}$ of Krebs Henseleit Bicarbonate medium containing fatty acid-poor albumin $(20 \mathrm{mg} / \mathrm{ml}), 5 \mathrm{mM}$ glucose, $0.2 \mathrm{mM}$ palmitate (unlabelled) and other additions. Incubations were under $\mathrm{O}_{2} / \mathrm{CO}_{2}$ $(19: 1)$ at $37^{\circ} \mathrm{C}$ and were terminated at $60 \mathrm{~min}$ by injection through the stoppers of $0.5 \mathrm{ml}$ of benzethonium hydroxide $(1 \mathrm{M}$ in methanol) into the centre well and $0.32 \mathrm{ml}$ of $60 \%$ (w/v) $\mathrm{HClO}_{4}$ into the outer compartment of each flask. The flasks were shaken for a further $1 \mathrm{~h}$, after which the contents of the centre well were taken for scintillation counting. Blank incubations contained $\left[{ }^{14} \mathrm{C}\right]$ palmitate without muscle strips.

\section{Measurement of the specific radioactivity of fatty acids in muscle triacylglycerols}

Each muscle strip was preincubated for $30 \mathrm{~min}$ as described above in the presence of $0.2 \mathrm{mM}\left[\mathrm{U}-{ }^{14} \mathrm{C}\right]$ palmitate. After removal and washing in Krebs Henseleit Bicarbonate medium they were homogenized in $20 \mathrm{vol}$. of $\mathrm{CHCl}_{3} /$ methanol $(2: 1, \mathrm{v} / \mathrm{v})$, sonicated every $10-15 \mathrm{~min}$ in a bath sonicator over the following $90 \mathrm{~min}$. After the homogenate had been filtered through Whatman No. 1 filter paper, 2 vol. of distilled water were added to the filtrate followed by centrifugation for $5 \mathrm{~min}$ at $2000 \mathrm{~g}_{\text {av }}$. The lower $\mathrm{CHCl}_{3}$ phase was evaporated to dryness under oxygen-free nitrogen. The residue was redissolved in $100 \mu \mathrm{l}$ of $\mathrm{CHCl}_{3}$ and lipid classes were separated by TLC with light petroleum (b.p. $\left.40-60{ }^{\circ} \mathrm{C}\right) /$ diethyl ether/acetic acid/methanol $(90: 20: 3: 2$, by vol.) for $90 \mathrm{~min}$. Lipid spots were revealed with $\mathrm{I}_{2}$ vapour and taken for scintillation counting. An aliquot of the residue was resuspended in $1.2 \mathrm{ml}$ of $74 \mathrm{mM}$ Tris/citrate buffer, $\mathrm{pH} \mathrm{8.2,}$ containing $7.9 \mathrm{mM}$ sodium cholate and $2 \%(\mathrm{w} / \mathrm{v})$ polyethylene glycol followed by spectrophotometric assay of triacylglycerol with a kit supplied by Boehringer. Calculations of the specific radioactivity of triacylglycerol were made only with extracts that contained negligible radioactivity in the TLC spots corresponding to diacylglycerol or monoacylglycerol.

\section{Measurement of enzyme activities in skeletal muscles}

Muscles were minced in ice-cold $0.15 \mathrm{M} \mathrm{KCl}$ and then rinsed several times in ice-cold $5 \mathrm{mM}$ Tris $/ \mathrm{HCl}$ buffer, $\mathrm{pH} 7.4$, containing $0.1 \mathrm{M} \mathrm{KCl}, 5 \mathrm{mM} \mathrm{MgSO}_{4}$ and $1 \mathrm{mM}$ EDTA, followed by homogenization at $0-2{ }^{\circ} \mathrm{C}$ in $10 \mathrm{vol}$. of the same buffer in a Potter-Elvehjem glass homogenizer fitter with a rotating Teflon pestle. The homogenate was centrifuged at $620 \mathrm{~g}_{\text {av }}$ for $10 \mathrm{~min}$ at $4{ }^{\circ} \mathrm{C}$ and the supernatant was then recentrifuged as before to remove any residual myofibrils. The resulting supernatant was centrifuged at $1400 \boldsymbol{g}_{\text {av }}$ for $10 \mathrm{~min}$ at $4{ }^{\circ} \mathrm{C}$ to obtain a mitochondrial fraction. This was resuspended in the homogenization medium and then recentrifuged at $1400 \boldsymbol{g}_{\text {av }}$ as before followed by resuspension in $0.15 \mathrm{M} \mathrm{KCl}$ and storage at $-70^{\circ} \mathrm{C}$. The postmitochondrial supernatant was centrifuged at $4{ }^{\circ} \mathrm{C}$ for $1 \mathrm{~h}$ at $105000 \boldsymbol{g}_{\text {av }}$ and the resulting supernatant (cytosolic fraction) was stored at $-70{ }^{\circ} \mathrm{C}$.

ATP: citrate oxaloacetate-lyase (EC 4.1.3.8) was assayed spectrophotometrically at $26^{\circ} \mathrm{C}$ [45] in a final volume of $1.0 \mathrm{ml}$ with approx. $400 \mu \mathrm{g}$ of cytosolic fraction protein. ACC was assayed radiochemically at $37^{\circ} \mathrm{C}$ [46] in a final volume of $1.0 \mathrm{ml}$ with approx. $200 \mu \mathrm{g}$ of cytosolic fraction protein. Half of the assays contained $10 \mathrm{mM}$ trisodium citrate and $10 \mathrm{mM} \mathrm{MgCl}_{2}$ [46], allowing the measurement of citrate-dependent and citrateindependent carboxylase activity. Fatty acid synthase (EC 2.3.1.85) was assayed radiochemically at $37^{\circ} \mathrm{C}$ [47] in a final volume of $1.0 \mathrm{ml}$ with approx. $400 \mu \mathrm{g}$ of cytosolic fraction protein. For the spectrophotometric assay of malonyl-CoA decarboxylase (MDC; EC 4.1.1.9) at $37{ }^{\circ} \mathrm{C}$ [48] a reaction mixture initially containing $0.1 \mathrm{M}$ Tris $/ \mathrm{HCl}$ buffer, $\mathrm{pH} 8.0,0.5 \mathrm{mM}$ dithiothreitol, $10 \mathrm{mM}$ L-malate, $0.5 \mathrm{mM} \mathrm{NAD}^{+}, 40 \mu \mathrm{M}$ rotenone and $1.4 \mu \mathrm{g}$ of malate dehydrogenase (1.7 units) was preincubated for $7 \mathrm{~min}$ after which $10 \mu \mathrm{g}$ of citrate synthase (CS; EC 4.1.4.7) (1.7 units) was added. After $1 \mathrm{~min}$ the reaction was initiated by addition of $0.3 \mathrm{mM}$ malonyl-CoA and approx. 35 or $170 \mu \mathrm{g}$ of frozen/thawed mitochondrial or cytosolic fraction protein respectively. The final volume was $1.0 \mathrm{ml}$. CS was assayed spectrophotometrically at $25^{\circ} \mathrm{C}$ [49] in a final volume of $1.0 \mathrm{ml}$ with approx. 5 or $15 \mu \mathrm{g}$ of mitochondrial or cytosolic fraction protein respectively.

\section{Statistical methods}

Values in Tables are given as means \pm S.E.M. Values of $n$ refer to the number of separate muscle preparations. Statistical significance was evaluated with Student's $t$ test.

\section{RESULTS AND DISCUSSION}

\section{Experiments with incubated soleus muscle}

In Expts. 1-5 (Table 1) muscle strips were, except in part of Expt. 1 , incubated with glucose as sole exogenous substrate; i.e. any 


\section{Table 1 Metabolite contents of incubated soleus muscle strips}

Muscle strips were preincubated for $30 \mathrm{~min}$ with $5 \mathrm{mM}$ glucose and albumin $(20 \mathrm{mg} / \mathrm{ml})$ followed by incubation for $60 \mathrm{~min}$ with $5 \mathrm{mM}$ glucose and albumin (20 mg/ml) and the indicated additions as described in the Materials and methods section. Values are expressed as nmol/g wet wt. of muscle and are means \pm S.E.M.; $n=4$ except for malonyl-CoA in Expts. 1 and 4 ( $n=5$ ), fatty acyl-CoA in Expt. $4(n=5)$ and Expt. $2\left(n=5\right.$ throughout). ${ }^{*, *, * \star \star \star * \star \star \star \star \star} P<0.05, P<0.025, P<0.01, P<0.005$ respectively compared with incubations with no addition (paired test). $\dagger, \dagger+\dagger \dagger, \dagger \dagger+P<0.05, P<0.025, P<0.005, P<0.0005$ respectively compared with incubations with insulin alone (paired test). $+,+\$ P<0.01, P<0.005$ respectively for comparison of incubations with AICAR alone with those incubated with AICAR plus insulin (paired test).

\begin{tabular}{|c|c|c|c|c|c|c|}
\hline \multirow[b]{2}{*}{ Expt. } & \multirow[b]{2}{*}{ Addition to incubation } & \multicolumn{4}{|c|}{ Concentration (nmol/g wet wt.) } & \multirow[b]{2}{*}{ Ratio, B to A } \\
\hline & & Malonyl-CoA & $\begin{array}{l}\text { Long-chain fatty } \\
\text { acyl-CoA (A) }\end{array}$ & $\begin{array}{l}\text { Long-chain } \\
\text { acylcarnitine (B) }\end{array}$ & $\begin{array}{l}\text { Total long-chain } \\
\text { esters }(A+B)\end{array}$ & \\
\hline \multirow[t]{4}{*}{1} & None & $1.6 \pm 0.2$ & $4.3 \pm 0.8$ & $22.5 \pm 1.7$ & $27 \pm 2$ & $5.9 \pm 1.3$ \\
\hline & Insulin (10 nM) & $2.9 \pm 0.3^{\star \star \star \star}$ & $8.6 \pm 1.8^{\star}$ & $17.4 \pm 3.2$ & $26 \pm 4$ & $2.3 \pm 0.7^{\star \star \star}$ \\
\hline & Palmitate $(0.5 \mathrm{mM})$ & $1.4 \pm 0.1$ & $4.0 \pm 0.7$ & $37.9 \pm 6.3$ & $42 \pm 5$ & $11.3 \pm 3.5$ \\
\hline & Insulin + palmitate & $1.2 \pm 0.1 \dagger \dagger \dagger$ & $3.3 \pm 0.6+t$ & $30.4 \pm 7.2$ & $34 \pm 7$ & $9.6 \pm 2.4 t$ \\
\hline \multirow[t]{2}{*}{2} & None & $1.5 \pm 0.2$ & $5.2 \pm 0.5$ & $39.2 \pm 3.7$ & $44 \pm 3$ & $8.1 \pm 1.5$ \\
\hline & Etomoxir (50 $\mu \mathrm{M})$ & $1.3 \pm 0.2$ & $9.3 \pm 2.0^{\star *}$ & $31.1 \pm 2.9$ & $40 \pm 4$ & $3.8 \pm 0.7^{\star \star}$ \\
\hline \multirow[t]{4}{*}{3} & Insulin (10 nM) & $2.2 \pm 0.5$ & $7.8 \pm 1.0$ & $12.8 \pm 2.8$ & $21 \pm 4$ & $1.6 \pm 0.3$ \\
\hline & Insulin $+0.1 \mu \mathrm{M}$ isoprenaline & $1.0 \pm 0.2 \dagger \dagger$ & $5.3 \pm 0.3 \dagger$ & $16.6 \pm 3.7$ & $22 \pm 4$ & $3.1 \pm 0.6 \dagger$ \\
\hline & Insulin +1 $\mu \mathrm{M}$ isoprenaline & $1.1 \pm 0.2 \dagger \dagger$ & $4.6 \pm 0.4 \dagger \dagger$ & $27.3 \pm 3.8+\dagger$ & $32 \pm 4 \dagger$ & $6.0 \pm 0.8+\dagger$ \\
\hline & Insulin $+10 \mu \mathrm{M}$ isoprenaline & $0.6 \pm 0.1+\dagger$ & $3.5 \pm 0.5 \dagger \dagger$ & $54.7 \pm 13.2 \dagger$ & $58 \pm 13 \dagger$ & $16.8 \pm 4.5+\dagger$ \\
\hline \multirow[t]{4}{*}{4} & Insulin (10 nM) & $2.4 \pm 0.3$ & $9.2 \pm 0.9$ & $12.9 \pm 1.2$ & $22 \pm 2$ & $1.4 \pm 0.1$ \\
\hline & Insulin + 1 mM AICAR & $0.9 \pm 0.3+\dagger+\dagger$ & $7.4 \pm 0.5+t$ & $10.3 \pm 1.7$ & $17 \pm 2 \dagger$ & $1.5 \pm 0.2 \%$ \\
\hline & AICAR $(1 \mathrm{mM})$ & $0.6+0.2$ & $4.6+0.4$ & $13.4+2.0$ & $18+2$ & $2.8+0.1$ \\
\hline & Insulin + DCA (3 mM) & $3.1 \pm 0.5$ & $8.3 \pm 1.3$ & $11.8 \pm 2.7$ & $19 \pm 4$ & $1.5 \pm 0.2$ \\
\hline \multirow[t]{2}{*}{5} & None & $0.7 \pm 0.1$ & $4.8 \pm 0.5$ & $34.7 \pm 3.4$ & $39 \pm 4$ & $7.3 \pm 0.2$ \\
\hline & $\mathrm{DCA}(3 \mathrm{mM})$ & $1.8 \pm 0.2^{* \star \star}$ & $7.9 \pm 1.1^{*}$ & $40.7 \pm 4.2$ & $49 \pm 5$ & $5.3 \pm 0.5^{\star *}$ \\
\hline
\end{tabular}

Table 2 Effects of isoprenaline, AICAribose and DCA on oxidation of fatty acids by incubated soleus muscle strips

Muscle strips were preincubated for $30 \mathrm{~min}$ with $5 \mathrm{mM}$ glucose, albumin $(20 \mathrm{mg} / \mathrm{ml}$ ) and $0.2 \mathrm{mM}$ palmitate (labelled or unlabelled) followed by incubation for $60 \mathrm{~min}$ with $5 \mathrm{mM}$ glucose, albumin $(20 \mathrm{mg} / \mathrm{ml}), 0.2 \mathrm{mM}$ palmitate (labelled or unlabelled) and the indicated additions. The values are means \pm S.E.M. $(n=5) .{ }^{*, * *, * * *, * * * \star} P<0.05, P<0.025, P<0.01, P<0.005$ respectively for effects of isoprenaline, DCA or AICAribose (paired test).

\begin{tabular}{|c|c|c|c|c|c|}
\hline Expt. & Addition to incubation & $\begin{array}{l}\text { Exogenous oxidation } \\
\text { (d.p.m./h per g } \\
\text { wet wt.) (A) }\end{array}$ & $\begin{array}{l}\text { Endogenous oxidation } \\
\text { (d.p.m./h per g } \\
\text { wet wt.) (B) }\end{array}$ & Ratio, $A$ to $B$ & $\begin{array}{l}\text { Exogenous oxidation } \\
\text { (nmol of } \mathrm{CO}_{2} / \mathrm{h} \\
\text { per } \mathrm{g} \text { wet } \mathrm{wt} \text {.) }\end{array}$ \\
\hline $\begin{array}{l}6 \\
7\end{array}$ & $\begin{array}{l}\text { Insulin }(10 \mathrm{nM}) \\
\text { Insulin }+0.1 \mu \mathrm{M} \text { isoprenaline } \\
\text { Insulin }(10 \mathrm{nM}) \\
\text { Insulin }+1 \mathrm{mM} \text { AICAribose } \\
\text { None } \\
\text { DCA }(3 \mathrm{mM})\end{array}$ & $\begin{array}{l}8737 \pm 1128 \\
11195 \pm 1676^{\star \star} \\
7759 \pm 651 \\
15675 \pm 1611^{\star \star \star \star} \\
13034 \pm 1572 \\
4110 \pm 416^{\star \star \star \star}\end{array}$ & $\begin{array}{l}2287 \pm 450 \\
4662 \pm 530^{\star \star \star} \\
5601 \pm 514 \\
5603 \pm 1352 \\
6837 \pm 758 \\
4439 \pm 630^{\star \star \star \star}\end{array}$ & $\begin{array}{l}4.5 \pm 1.2 \\
2.4 \pm 0.2^{\star} \\
1.4 \pm 0.2 \\
3.4 \pm 0.7^{\star} \\
2.1 \pm 0.4 \\
1.0 \pm 0.2^{\star \star \star}\end{array}$ & $\begin{array}{l}489 \pm 63 \\
627 \pm 94^{\star \star} \\
447 \pm 34 \\
903 \pm 87^{\star \star \star \star} \\
760 \pm 91 \\
236 \pm 23^{\star \star \star \star}\end{array}$ \\
\hline
\end{tabular}

fatty acid that was oxidized would have been derived from the turnover of endogenous lipids (presumably triacylglycerols), and tissue long-chain acyl-CoAs and acylcarnitines would have been derived from the same source. Expts. 6-8 (Table 2) measured changes in fatty acid oxidation, which necessitated the addition of $\left[{ }^{14} \mathrm{C}\right]$ palmitate; $0.2 \mathrm{mM}$ was chosen as the most suitable concentration because, with this, a substantial (58\%) decrease in oxidation was observed with insulin (Figure 2). By prelabelling muscle lipids during the preincubation we were able also to obtain some index of the oxidation of fatty acids derived from endogenous sources. The mean content of triacylglycerol in muscle strips at the end of preincubation with $0.2 \mathrm{mM}$ palmitate (specific radioactivity 220 d.p.m. per nmol) was $272 \pm 50 \mathrm{nmol} / \mathrm{g}$ wet wt. $(n=8)$ with an overall specific radioactivity of only $13 \pm 2$ d.p.m. per nmol of fatty acid. If this was the actual specific activity of triacylglycerol that was turned over, the absolute rates of endogenous fatty acid oxidation would be improbably high (2815-8415 nmol of $\mathrm{CO}_{2} / \mathrm{h}$ per $\mathrm{g}$ wet wt.). Nevertheless, as discussed below, paired changes in the ratio of d.p.m. in $\mathrm{CO}_{2}$ derived from endogenous and exogenous sources are informative.

\section{Effects of insulin and etomoxir}

As described previously [27,28], insulin increased the tissue content of malonyl-CoA (Expt. 1, Table 1). Insulin also doubled the tissue content of long-chain fatty acyl-CoA and significantly decreased the ratio of fatty acylcarnitine to fatty acyl-CoA. When all of the data for different experiments were pooled and compared by an unpaired $t$ test (Table 3 ), a significant effect of insulin to decrease the tissue content of long-chain acylcarnitine was also seen. As reviewed in [50], the degree to which long-chain acyl-CoA esters are compartmented between mitochondria and cytosol is unresolved. To address the question of whether an increase in the content of long-chain fatty acyl-CoA together with a decrease in the ratio of fatty acylcarnitine to fatty acylCoA might be a reasonable diagnostic of a 'metabolic crossover', 


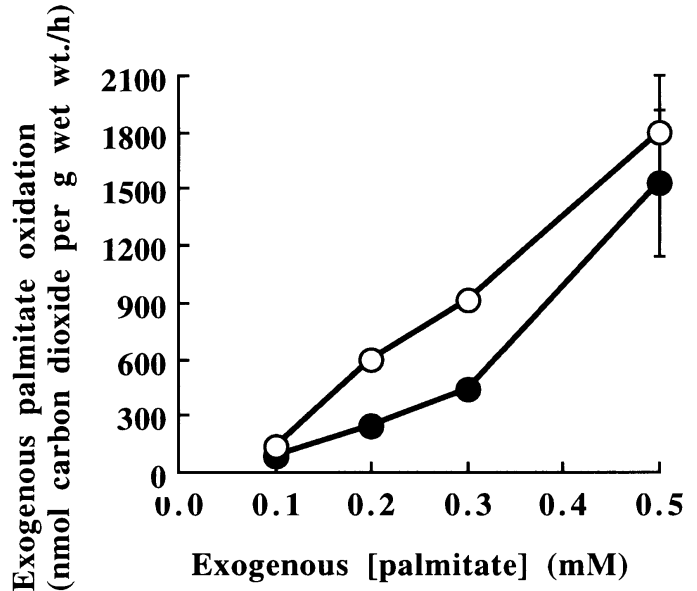

Figure 2 Effect of insulin on oxidation of exogenous fatty acid by incubated soleus muscle strips

Muscle strips were preincubated for $30 \mathrm{~min}$ with $5 \mathrm{mM}$ glucose, albumin $(20 \mathrm{mg} / \mathrm{ml})$ and $0.2 \mathrm{mM}$ unlabelled palmitate followed by incubation for $60 \mathrm{~min}$ with $5 \mathrm{mM}$ glucose, albumin $(20 \mathrm{mg} / \mathrm{ml})$ and the indicated concentration of $\left[U^{14} \mathrm{C}\right]$ palmitate. The values are means \pm range of values for two separate experiments performed in duplicate. Symbols: $\bigcirc$, without insulin; , with insulin $(10 \mathrm{nM})$

implying the inhibition of $\mathrm{CPT}_{1}$, we investigated the effects of etomoxir (Expt. 2, Table 1). The CoA ester of this drug is a potent and irreversible inhibitor of $\mathrm{CPT}_{1}$ [51] but has little effect on the latent form of the enzyme. Etomoxir increased the tissue content of long-chain fatty acyl-CoA with a decrease in the ratio of fatty acylcarnitine to fatty acyl-CoA. It is reasonable to conclude that these changes followed from inhibition of $\mathrm{CPT}_{1}$ and that the increase in fatty acyl-CoA was 'upstream' of $\mathrm{CPT}_{1}$, i.e. in a cytosolic (and intermembrane space) pool. We therefore suggest that the changes seen with insulin could also be due to inhibition of $\mathrm{CPT}_{1}$; this would be consistent with the decrease in oxidation of $\left[{ }^{14} \mathrm{C}\right]$ palmitate seen with insulin (Figure 2). From the pooled data in Table 3 it was apparent that insulin decreased the total pool of acylcarnitine plus acyl-CoA, suggesting that insulin might be antilipolytic in soleus muscle. If so, insulin could not increase the oxidation of fatty acids derived from endogenous sources and therefore must decrease total (endogenous plus exogenous) oxidation.

\section{Effects of isoprenaline}

We tested the effects of the $\beta$-adrenergic agonist isoprenaline because plasma catecholamine concentrations [52] and muscle
cAMP concentrations [42,53] increase in exercise. Isoprenaline opposed all of the effects of insulin (Expt. 3, Table 1); i.e. it decreased the malonyl-CoA content to basal values, decreased long-chain fatty acyl-CoA content, increased long-chain fatty acylcarnitine content and increased the ratio of fatty acylcarnitine to fatty acyl-CoA. At even the lowest concentration tested $(0.1 \mu \mathrm{M})$, isoprenaline enhanced $\beta$-oxidation (Expt. 6, Table 2). We suggest that these effects are consistent with an activation of $\mathrm{CPT}_{1}$. The observations that isoprenaline increased the oxidation of endogenous fatty acids by a greater extent than the oxidation of exogenous palmitate (104\% and $28 \%$ increases respectively) and increased the content of the total long-chain esters are consistent with the notion that intracellular lipolysis in skeletal muscle can be activated by a cAMP-dependent mechanism [54], presumably involving hormone-sensitive lipase, which is present in skeletal muscle [55]. The question arises as to the cause of the decrease in malonyl-CoA content with isoprenaline. In rat perfused hindlimb, catecholamines, like insulin, increase glycolysis [56], suggesting that catecholamines are unlikely to decrease the availability of acetyl-CoA and/or citrate for muscle ACC. However, it is not known whether this 'blanket' conclusion is appropriate for different muscle types. For example, in the exercising adrenomedullated rat, adrenaline increases the contents of lactate and fructose 6-phosphate in both red and white quadriceps muscle [53]. However, whereas the content of fructose 2,6-bisphosphate was increased by adrenaline in white muscle, it was decreased in red muscle [53]. Long-chain fatty acyl-CoA esters cause the allosteric inhibition of liver ACC [57] but we have observed a decrease rather than an increase in these with isoprenaline. With regard to protein phosphorylation, skeletal muscle ACC can be phosphorylated by cAMP-dependent protein kinase [58] but this has no effect whatsoever on the kinetic properties of the enzyme. We suggest that the phosphorylation and inactivation of muscle ACC in response to isoprenaline might occur via the action of the AMPK if this protein kinase could be activated as a consequence of increased fatty acid/fatty acyl-CoA turnover in the muscle (see below). We also noted that higher concentrations of isoprenaline $(1$ or $10 \mu \mathrm{M})$ further increased the ratio of fatty acylcarnitine to fatty acyl-CoA, suggesting some further activation of $\mathrm{CPT}_{1}$ that is essentially independent of any further decrease in the whole tissue content of malonyl-CoA (Table 1). It is possible that with the higher concentrations of this agonist other factors could activate or deinhibit $\mathrm{CPT}_{1}$ or that the 'sequestration' of malonyl-CoA at intracellular binding sites might be increased.

\section{Effects of palmitate}

Palmitate reversed changes seen with insulin; i.e. it abolished the increase in malonyl-CoA content, decreased the tissue content of long-chain fatty acyl-CoA and increased the ratio of fatty

Table 3 Metabolite contents of incubated soleus muscle strips

Pooled values (as nmol/g wet wt. of muscle) were collected from the various experiments shown in Table 1 and were then compared by using an unpaired $t$ test. Values are means \pm S.E.M. Numbers of measurements are shown in square brackets. ${ }^{\star \star \star}{ }^{\star \star} P<0.01, P<0.001$ respectively compared with the basal condition.

\begin{tabular}{|c|c|c|c|}
\hline Measurement & Addition to incubation ... None & Insulin & AlCAribose \\
\hline Malonyl-CoA & $1.3 \pm 0.2[14]$ & $2.5 \pm 0.2^{* *}[14]$ & $0.6 \pm 0.2^{\star}[5]$ \\
\hline Fatty acyl-CoA (A) & $4.8 \pm 0.3[13]$ & $8.6 \pm 0.6^{\star *}[13]$ & $4.6 \pm 0.4[5]$ \\
\hline Fatty acylcarnitine (B) & $32.6 \pm 2.6[13]$ & $14.4 \pm 1.5^{\star \star}[12]$ & $13.4 \pm 2.0^{\star \star}[4]$ \\
\hline Total long-chain esters $(A+B)$ & $37 \pm 3[13]$ & $23 \pm 2^{* *}[12]$ & $18 \pm 2^{\star \star}[4]$ \\
\hline Ratio, B to A & $7.2 \pm 0.7[13]$ & $1.8 \pm 0.3^{* *}[12]$ & $2.8 \pm 0.1^{\star \star}[4]$ \\
\hline
\end{tabular}




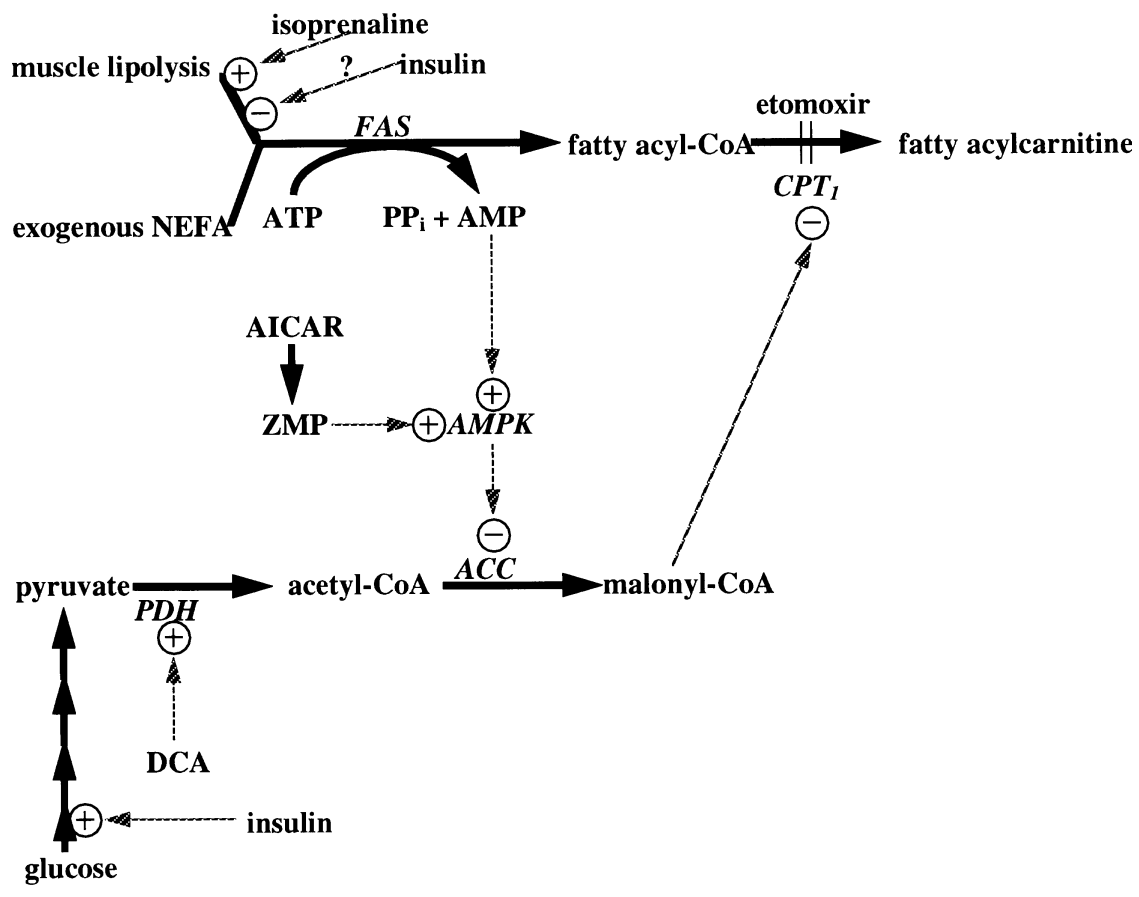

Scheme 1 Scheme to summarize factors influencing contents of metabolites in soleus muscle

See the text for further details.

acylcarnitine to fatty acyl-CoA (Expt. 1, Table 1). Likewise, raising the concentration of $\left[{ }^{14} \mathrm{C}\right]$ palmitate to $0.5 \mathrm{mM}$ abolished the effect of insulin in decreasing fatty acid oxidation (Figure 2). This interplay between insulin and fatty acid has physiological implications for intracellular fatty acid disposition during nutritional transitions and in this context it is noteworthy that glucose utilization by skeletal muscle in vivo is suppressed by elevated fatty acid levels when insulin levels are low [59].

The effects of $0.5 \mathrm{mM}$ palmitate were very similar to those seen with isoprenaline. The increased provision of long-chain fatty acids from either exogenous or endogenous sources is likely to result in increased throughput at the fatty acyl-CoA synthetase reaction with the concomitant formation of AMP (Scheme 1). If this was sufficient to cause the activation of AMPK (or AMPK kinase) the decrease in malonyl-CoA content with palmitate or isoprenaline could be explained and it would be envisaged that fatty acids cause feedforward activation of their own oxidative disposal. In this context, Hardie and Carling [34] have suggested that the activation of AMPK might occur in adipocytes under lipolytic conditions as a result of AMP formation by fatty acylCoA synthetase.

\section{Effects of AICAriboside}

The 5'-AMP analogue ZMP can mimic the effect of AMP to activate AMPK allosterically [60] and its upstream AMPK kinase [61]. Administration of the cell-permeable dephosphorylated form AICAriboside causes ZMP to accumulate inside cells [62] provided that the cells have sufficient adenosine kinase activity to phosphorylate AICAriboside. The addition of AICAriboside to hepatocytes or adipocytes causes downstream changes that are consistent with activation of AMPK; i.e. inactivation of HMG-CoA reductase, decreased sterol and fatty acid synthesis and inhibition of lipolysis [34]. We therefore investigated the effects of AICAriboside on soleus muscle (Expt. 4, Table 1; Expt. 7, Table 2) with the expectation that, like palmitate or isoprenaline, AICAriboside would be antagonistic to insulin. With $1 \mathrm{mM}$ AICAriboside ZMP was measurable in the acid-soluble tissue extract $(428 \mathrm{nmol} / \mathrm{g}$ wet wt.; $n=2)$ but ZMP was not detectable in controls. AICAriboside (in the presence of insulin) was at least as effective as isoprenaline or palmitate in abolishing the insulin-dependent increase in malonyl$\mathrm{CoA}$ and in increasing $\beta$-oxidation, changes that would be expected if an insulin-mediated inactivation of $\mathrm{CPT}_{1}$ were being opposed. However, AICAriboside was only partly effective in opposing the increase in long-chain fatty acyl-CoA seen with insulin. The persistence of the insulin-induced elevation in fatty acyl-CoA even when AICAriboside decreases malonyl-CoA content (and presumably also $\mathrm{CPT}_{1}$ activity) suggests that AICAriboside blocks an alternative route of disposal of cytosolic fatty acyl-CoA, e.g. glycerolipid synthesis. We also deduced that, as in adipocytes, AICAriboside inhibited lipolysis because it increased the oxidation of exogenous fatty acids relative to that of endogenous fatty acids (Table 2) and decreased the total pool of long-chain acyl esters (Table 1). Table 3 shows a comparison (unpaired basis) of values obtained with AICAriboside alone with basal measurements. Even under basal conditions AICAriboside significantly decreased malonyl-CoA content and decreased the total content of fatty acyl esters.

\section{Effects of DCA}

In perfused rat hearts DCA enhances the inhibition of oleate oxidation by lactate or pyruvate [21] and decreases fatty acid oxidation and increases malonyl-CoA content when glucose is present $[63,64]$. In soleus muscle $3 \mathrm{mM}$ DCA had similar effects to those of insulin: malonyl-CoA and long-chain fatty acyl-CoA contents were increased significantly, the ratio of fatty acylcarnitine to fatty acyl-CoA was decreased and fatty acid oxidation 


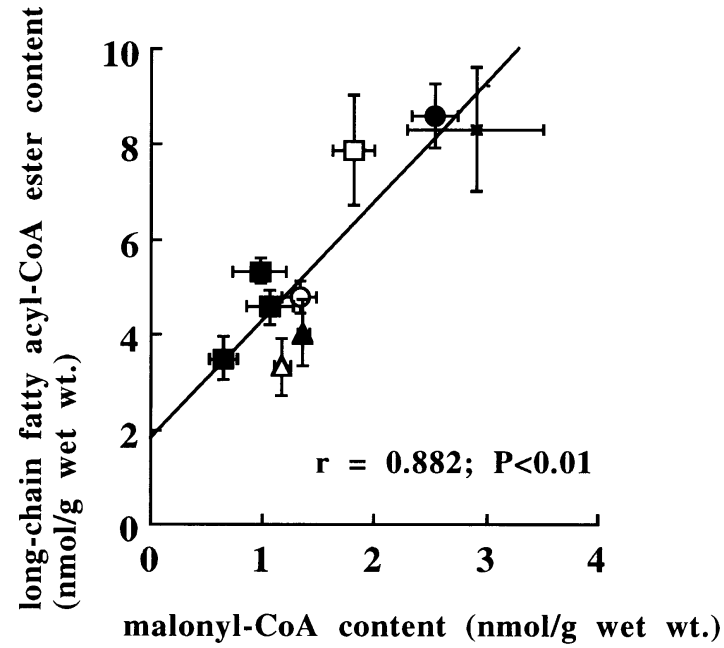

Figure 3 Linear correlation between tissue contents of malonyl-CoA and long-chain fatty acyl-CoA esters

Values, shown as means \pm S.E.M., were obtained in the experiments summarized in Table 1. The regression line $y=2.48 x+1.81$ is fitted to the points. Symbols: $\bigcirc$, basal; 0 , insulin; $\boldsymbol{\Delta}$. palmitate; $\triangle$, palmitate + insulin; $\boldsymbol{\square}$, isoprenaline $(0.1-10 \mu \mathrm{M})+$ insulin; $\square$, DCA $(3 \mathrm{mM}) ; \times$, DCA $(3 \mathrm{mM})+$ insulin.

was decreased (Expt. 5, Table 1). When DCA and insulin were added in combination (Expt. 4, Table 1) their effects were nonadditive, supporting the conclusion of Saha et al. [28] that insulin increases malonyl-CoA content in soleus muscle by enhancing the conversion of carbohydrate precursors into acetyl-CoA (and citrate). However, an unexpected effect of DCA was also noted. Although $3 \mathrm{mM}$ DCA decreased the oxidation of both exogenous and endogenous fatty acids the share of this from endogenous sources was increased significantly (Expt. 8, Table 2), i.e. DCA must have had a lipolytic effect. The mechanism underlying this is not understood.

\section{Correlation between fatty acyl-CoA and malonyl-CoA contents}

Saha et al. [65] have suggested that an increase in cytosolic fatty acyl-CoA would follow from an increase in malonyl-CoA, but provided no measurements in support of this. We now offer support for this proposal. Figure 3 shows data from all experiments except those with AICAriboside, and indicates a significant correlation between the tissue contents of malonyl-CoA and long-chain fatty acyl-CoA. Figure 3 also suggests that there is a muscle pool of long-chain fatty acyl-CoA of approx. $1.8 \mathrm{nmol} / \mathrm{g}$ wet wt. whose content is unaffected by malonyl-CoA/CPT activity and whose location is unknown. In this regard it is noteworthy that there is a significant positive linear correlation between long-chain fatty acyl-CoA content in pooled soleus/ gastrocnemius/plantaris muscle and plasma insulin concentration in rats fed with a high-fat diet (see Figure 4 of [66]), again with a positive intercept on the fatty acyl-CoA axis.

\section{Measurements of enzyme activities in rat skeletal muscles}

The observed changes in malonyl-CoA must have resulted from changes in the formation and/or disposal of malonyl-CoA. We therefore investigated the potential for these processes under conditions approximating to $V_{\max }$ (Tables 4 and 5). Enzyme activities in soleus muscle (Type I) were compared with those in two representative Type IIa muscles [extensor digitorum longus (EDL) and tibialis anterior] and in the gastrocnemius, a predominantly Type IIb muscle.

\section{Malonyl-CoA formation}

In all four muscles acetyl-CoA-dependent bicarbonate fixation was highly citrate-dependent, in agreement with earlier studies $[32,33,58]$. At the time of dissection and extraction ACC might have different degrees of phosphorylation in different muscles, which could affect the true measurement of activity. The ACC values shown in Table 4 are therefore minimum estimates although, because we chose not to include protein phosphatase

Table 4 Enzyme activities in soluble extracts from four skeletal muscle types

Measurements were made in $105000 \mathrm{~g}$ supernatants as described in the Materials and methods section. Activities, expressed as nmol/min per $\mathrm{g}$ wet wt. or per $\mathrm{mg}$ of soluble protein, are shown as means \pm S.E.M. ( $n=4$ in every case).

Enzyme activity (nmol/min per $\mathrm{g}$ wet wt., or $\mathrm{nmol} / \mathrm{min}$ per $\mathrm{mg}$ of soluble protein)

\begin{tabular}{llll}
\hline ATP: citrate & ACC & & \\
\cline { 2 - 3 } oxaloacetate-lyase & - Citrate $\quad+$ Citrate & Citrate-dependent & $\begin{array}{l}\text { Fatty acid } \\
\text { synthase }\end{array}$
\end{tabular}

EDL

\begin{tabular}{|c|c|c|c|c|c|}
\hline $\begin{array}{l}\text { Per g wet wt. } \\
\text { Per mg of protein } \\
\text { strocnemius }\end{array}$ & $\begin{array}{c}2.4 \pm 0.6 \\
0.33 \pm 0.04\end{array}$ & $0.4 \pm 0.1$ & $2.2 \pm 0.5$ & $\begin{array}{c}1.8 \pm 0.4 \\
0.25 \pm 0.03\end{array}$ & $0.43 \pm 0.05$ \\
\hline $\begin{array}{l}\text { Per g wet wt. } \\
\text { Per mg of protein } \\
\text { oleus }\end{array}$ & $\begin{array}{c}9.2 \pm 2.2 \\
0.55 \pm 0.10\end{array}$ & $0.5 \pm 0.1$ & $4.6 \pm 0.6$ & $\begin{array}{c}4.1 \pm 0.6 \\
0.25 \pm 0.01\end{array}$ & $0.42 \pm 0.08$ \\
\hline $\begin{array}{l}\text { Per g wet wt. } \\
\text { Per mg of protein } \\
\text { ibialis anterior }\end{array}$ & $\begin{array}{c}3.2 \pm 0.5 \\
0.51 \pm 0.08\end{array}$ & $0.5 \pm 0.2$ & $1.7 \pm 0.4$ & $\begin{array}{c}1.2 \pm 0.3 \\
0.19 \pm 0.04\end{array}$ & $0.31 \pm 0.09$ \\
\hline $\begin{array}{l}\text { Per g wet wt. } \\
\text { Per mg of protein }\end{array}$ & $\begin{array}{c}9.3 \pm 1.6 \\
1.27 \pm 0.19\end{array}$ & $0.4 \pm 0.1$ & $3.5 \pm 1.3$ & $\begin{array}{c}3.1 \pm 1.3 \\
0.36 \pm 0.06\end{array}$ & $0.58 \pm 0.29$ \\
\hline
\end{tabular}




\section{Table 5 Calculation of cytosolic malonyl-CoA decarboxylase activity in three skeletal muscle types}

Measurements were made in mitochondrial fractions and in $105000 \mathrm{~g}$ supernatants as described in the Materials and methods section. Activities are expressed as $\mathrm{nmol} / \mathrm{min} \mathrm{per} \mathrm{g}$ wet wt. and are means \pm S.E.M. ( $n=4$ for EDL and $n=3$ for gastrocnemius and soleus).

\begin{tabular}{|c|c|c|c|c|c|c|c|}
\hline \multirow[b]{3}{*}{ Muscle type } & \multicolumn{4}{|c|}{ Enzyme activity (nmol/min per g wet wt.) } & \multirow[b]{3}{*}{$\begin{array}{l}1000 \times \text { Ratio, } \\
\text { A to C }\end{array}$} & \multirow[b]{3}{*}{$\begin{array}{l}1000 \times \text { Ratio, } \\
\text { B to D }\end{array}$} & \multirow{3}{*}{$\begin{array}{l}\text { Calculated } \\
\text { cytosolic } \\
\text { MDC activity } \\
\text { (nmol/min } \\
\text { per g wet wt. }\end{array}$} \\
\hline & \multicolumn{2}{|l|}{$\mathrm{MDC}$} & \multicolumn{2}{|l|}{ CS } & & & \\
\hline & $\begin{array}{l}\text { In mitochondrial } \\
\text { fraction (A) }\end{array}$ & $\begin{array}{l}\text { In cytosolic } \\
\text { fraction (B) }\end{array}$ & $\begin{array}{l}\text { In mitochondrial } \\
\text { fraction (C) }\end{array}$ & $\begin{array}{l}\text { In cytosolic } \\
\text { fraction (D) }\end{array}$ & & & \\
\hline EDL & $0.7 \pm 0.1$ & $6.2 \pm 0.5$ & $397 \pm 60$ & $963 \pm 130$ & 1.76 & 6.44 & $4.5 \pm 0.5$ \\
\hline Gastrocnemius & $4.1 \pm 1.8$ & $16.6 \pm 0.5$ & $829 \pm 198$ & $2138 \pm 293$ & 4.95 & 7.76 & $7.3 \pm 0.4$ \\
\hline Soleus & $2.5 \pm 0.2$ & $14.8 \pm 3.8$ & $1126 \pm 371$ & $1310 \pm 253$ & 2.22 & 11.30 & $11.7 \pm 3.7$ \\
\hline
\end{tabular}

inhibitors in the extraction buffer, it is to be expected that the ACC activities measured largely reflect the dephosphorylated state. When expressed per $\mathrm{g}$ of tissue there seemed to be appreciable differences in ACC activity between the four muscle types. However, when expressed relative to soluble protein these differences largely disappeared. All four muscle types contained ATP: citrate oxaloacetate-lyase activity that seemed sufficient to provide acetyl-CoA for ACC. The presence of ATP:citrate oxaloacetate-lyase could also be taken as an indication that cytosolic (rather than only mitochondrial) citrate is actually present in skeletal muscles and therefore could have a role as an activator of muscle ACC.

\section{Malonyl-CoA disposal}

Fatty acid synthase was not detectable by spectrophotometric assay but low activities were detected radiochemically (Table 4). It was not possible to ascertain whether any of this activity is actually in muscle fibres or whether all or most of it might be in adipocytes within the muscle mass. The experiments shown in Table 5 addressed the question of whether cytosolic malonylCoA could be disposed of via MDC. MDC activity was found in both crude mitochondrial and cytosolic fractions. Because the mitochondrial fraction had minimal contamination by lactate dehydrogenase (results not shown) there must be a 'true' mitochondrial MDC activity in muscle. As evidenced by the considerable CS activity in the cytosolic fractions, fairly extensive enzyme leakage from mitochondria had occurred during homogenization, thereby complicating the estimation of any 'true' cytosolic activity of MDC. However, the activity ratio of MDC to CS was higher in the crude cytosolic fraction than in the crude mitochondrial fraction (particularly in the soleus and EDL muscles), suggesting the existence of some 'true' cytosolic MDC activity, which was then calculated as the ratio of leaked MDC activity to leaked CS activity, which was equal to the ratio of the MDC activity measured in the mitochondrial fraction to the CS activity measured in the mitochondrial fraction. From this the leaked MDC can be calculated as (measured mitochondrial MDC $\times$ leaked $\mathrm{CS}$ ) divided by measured mitochondrial CS; because 'true' cytosolic MDC is the measured cytosolic MDC minus the leaked MDC, the 'true' cytosolic MDC activity can be obtained by combining the latter two calculations.

At $37^{\circ} \mathrm{C}$ this 'true' cytosolic MDC activity was similar to or greater than citrate-dependent ACC activity and was considerably greater than fatty acid synthase activity by 10 -fold, 17-fold and 38 -fold in EDL, gastrocnemius and soleus muscles respectively. We therefore suggest that MDC provides a feasible route for the disposal of the malonyl-CoA formed by ACC in muscle cytosol. Further experiments should be undertaken to investigate whether this enzyme is subject to acute regulation.

We are grateful for support from the British Heart Foundation.

\section{REFERENCES}

1 McGarry, J. D. and Brown, N. F. (1997) Eur. J. Biochem. 244, 1-14

2 Saggerson, E. D. and Carpenter, C. A. (1981) FEBS Lett. 129, 229-232

3 Mills, S. E., Foster, D. W. and McGarry, J. D. (1983) Biochem. J. 214, 83-91

4 Lloyd, A. C., Carpenter, C. A. and Saggerson, E. D. (1986) Biochem. J. 237, 289-291

5 Trumble, G. E., Smith, M. A. and Winder, W. W. (1995) Eur. J. Biochem. 231, 192-198

6 Ha, J., Lee, J.-K., Kim, K.-S., Witters, L. A. and Kim, K.-H. (1996) Proc. Natl. Acad. Sci. U.S.A. 93, 11466-11470

7 Widmer, J., Fassihi, K. S., Schlichter, S. C., Wheeler, K. S., Crute, B. E., King, N., Nutile-McMenemy, N., Noll, W. W., Daniel, S., Ha, J. et al. (1996) Biochem. J. 316 915-922

8 Abu-Elheiga, L., Almarza-Ortega, D. B., Baldini, A. and Wakil, S. J. (1997) J. Biol. Chem. 272, 10669-10677

9 Randle, P. J., Garland, P. B., Hales, C. N. and Newsholme, E. A. (1963) Lancet i, 785-789

10 Randle, P. J., Priestman, D. A., Mistry, S. C. and Halsall, A. (1994) Diabetologia 37 (Suppl. 2), S155-S161

11 Rennie, M. J., Winder, W. W. and Holloszy, J. 0. (1976) Biochem. J. 156, 647-655

12 Maizels, E. Z., Ruderman, N. B., Goodman, M. N. and Lau, D. (1977) Biochem. J. 162, 557-568

13 Rennie, M. J. and Holloszy, J. O. (1977) Biochem. J. 168, 161-170

14 Zorzano, A., Balon, T. W., Brady, L. J., Rivera, P., Garetto, L. P., Young, J. C. Goodman, M. N. and Ruderman, N. M. (1985) Biochem. J. 232, 585-591

15 Issad, T., Pénicaud, L., Ferré, P., Kandé, J., Baudon, M.-A. and Girard, J. (1987) Biochem. J. 246, 241-244

16 Walker, M., Fulcher, G. R., Sum, C. F., Orskov, H. and Alberti, K. G. M. M. (1991) Am. J. Physiol. 261, E304-E311

17 Spitzer, J. J. (1974) Am. J. Physiol. 226, 213-217

18 Spitzer, J. J. and Spitzer, S. A. (1972) Am. J. Physiol. 222, 101-105

19 McDonough, K. H., Burns, A. H. and Spitzer, J. J. (1982) J. Mol. Cell. Cardiol. 14 (Suppl. 1), 49

20 Bielefeld, D. R., Vary, T. C. and Neely, J. R. (1985) J. Mol. Cell. Cardiol. 17, 619-625

21 Forsey, R. G. P., Reid, K. and Brosnan, J. T. (1987) Can. J. Physiol. Pharmacol. 65, 401-406

22 Montini, J., Bagby, G. T. and Spitzer, J. J. (1981) J. Mol. Cell. Cardiol. 13, 903-911

23 Awan, M. M. and Saggerson, E. D. (1993) Biochem. J. 295, 61-66

24 Taegtmeyer, H., Hems, R. and Krebs, H. A. (1980) Biochem. J. 186, 701-711

25 Kelley, D. E., Reilly, J. P., Veneman, T. and Mandarino, L. J. (1990) Am. J. Physiol. 258, E923-E929

26 Sidossis, L. S. and Wolfe, R. R. (1996) Am. J. Physiol. 270, E733-E738

27 Saha, A. K., Kurowski, T. G. and Ruderman, N. B. (1995) Am. J. Physiol. 269, E283-E289

28 Saha, A. K., Vavvas, D., Kurowski, T. G., Apazidis, A., Witters, L. A., Shafrir, E. and Ruderman, N. B. (1997) Am. J. Physiol. 272, E641-E648

29 Winder, W. W., MacLean, P. S., Lucas, J. C., Fernley, J. E. and Trumble, G. E. (1995) J. Appl. Physiol. 78, 578-582 
30 Winder, W. W. and Hardie, D. G. (1996) Am. J. Physiol. 270, E299-E304

31 Odland, L. M., Heigenhauser, G. J. F., Lopaschuk, G. D. and Spriet, L. L. (1996) Am. J. Physiol. 270, E541-E544

32 Hutber, C. A., Hardie, D. G. and Winder, W. W. (1997) Am. J. Physiol. 272 , E262-E266

33 Vavvas, D., Apazidis, A., Saha, A. K., Gamble, J., Patel, A., Kemp, B. E., Witters, L. A. and Ruderman, N. B. (1997) J. Biol. Chem. 272, 13255-13261

34 Hardie, D. G. and Carling, D. (1997) Eur. J. Biochem. 246, 259-273

35 Evans, W. H. and Mueller, P. S. (1963) J. Lipid Res. 4, 39-45

36 Leighton, B., Budohoski, L., Lozeman, F. J., Challiss, R. A. J. and Newsholme, E. A. (1985) Biochem. J. 227, 337-344

37 McGarry, J. D., Stark, M. J. and Foster, D. W. (1978) J. Biol. Chem. 253, 8291-8293

38 Singh, B., Stakkestad, J. A., Bremer, J. and Borrebaek, B. (1984) Anal. Biochem. 138, $107-111$

39 Abdinejad, A., Fisher, A. M. and Kumar, S. (1981) Arch. Biochem. Biophys. 208, $135-145$

40 Spriet, L. L., Dyck, D. J., Cederblad, G. and Hultman, E. (1992) Am. J. Physiol. 263 C653-C659

41 Dyck, D. J., Peters, S. J., Wendling, P. S. and Spriet, L. L. (1996) Am. J. Physiol. 270, R766-R776

42 Winder, W. W., Arogyasami, J., Barton, R. J., Elayan, I. M. and Vehrs, P. R. (1989) J. Appl. Physiol. 67, 2230-2233

43 Allred, J. B. and Guy, D. G. (1969) Anal. Biochem. 29, 293-299

44 Cederblad, G. and Lindstedt, S. (1972) Clin. Chim. Acta 37, 235-243

45 Martin, B. R. and Denton, R. M. (1970) Biochem. J. 117, 861-877

46 Holland, R., Witters, L. A. and Hardie, D. G. (1986) Eur. J. Biochem. 140, 325-333

47 Carey, E. M. and Dils, R. (1970) Biochim. Biophys. Acta 210, 371-387

48 Kim, Y. S. and Kolattukudy, P. E. (1978) Arch. Biochem. Biophys. 190, 234-246

49 Sheperd, D. and Garland, P. B. (1969) Biochem. J. 114, 597-610

Received 18 November 1997/9 April 1998; accepted 11 May 1998
50 Færgeman, N. J. and Knudsen, J. (1997) Biochem. J. 323, 1-12

51 Declercq, P. E., Falck, J. R., Kuwajima, M., Tyminski, H., Foster, D. W. and McGarry, J. D. (1987) J. Biol. Chem. 262, 9812-9821

52 Stanley, W. C. and Connett, R. J. (1991) FASEB J. 5, 2155-2159

53 Winder, W. W. and Duan, C. (1992) Am. J. Physiol. 262, E919-E924

54 Oscai, L. B., Essig, D. A. and Palmer, W. K. (1990) J. Appl. Physiol. 69, 1571-1577

55 Holm, C., Kirchgessner, T. G., Svenson, K. L., Fredrikson, G., Nilsson, S., Miller, C. G., Shively, J. E., Heinzmann, C., Sparkes, R. S., Mohandas, T. et al. (1988) Science 241, 1503-1506

56 Hue, L., Blackmore, P. F., Shikama, H., Robinson-Steiner, A. and Exton, J. H. (1982) J. Biol. Chem. 257, 4308-4313

57 Hardie, D. G. (1989) Prog. Lipid Res. 28, 117-146

58 Winder, W. W., Wilson, H. A., Hardie, D. G., Rasmussen, B. B., Hitber, C. A., Call, G. B., Clayton, R. D., Conley, L. M., Yoon, S. and Zhou, B. (1997) J. Appl. Physiol. 82, 219-225

59 Jenkins, A. B., Storlien, L. H., Chisholm, D. J. and Kraegen, E. W. (1988) J. Clin. Invest. 82, 293-299

60 Sullivan, J. E., Carey, F., Carling, D. and Beri, R. J. (1994) Biochem. Biophys. Res. Commun. 200, 1551-1556

61 Corton, J. M., Gillespie, J. G., Hawley, S. A. and Hardie, D. G. (1995) Eur. J. Biochem. 229, 558-565

62 Sabina, R. L., Patterson, D. and Holmes, E. W. (1985) J. Biol. Chem. 260 , 6107-6114

63 Saddik, M., Gamble, J., Witters, L. A. and Lopoaschuk, G. D. (1993) J. Biol. Chem. 268, 25836-25845

64 Lopaschuk, G. D. and Gamble, J. (1994) Can. J. Physiol. Pharmacol. 72, 1101-1109

65 Saha, A. K., Kurowski, T. G., Colca, J. R. and Ruderman, N. B. (1994) Am. J. Physiol. E95-E10

66 Chen, M.-T., Kaufman, L. N., Spennetta, T. and Shrago, E. (1992) Metabolism 41, $564-569$ 